\title{
An Economic Instrument to Improve Migration
}

\author{
Jan Stenis \\ Correspondence: Jan Stenis, Kristianstad, Sweden jan.stenis@icloud.com
}

Received: October 4, 2019

doi:10.11114/aef.v7i1.4630

\author{
Accepted: October 23, $2019 \quad$ Available online: November 27, 2019 \\ URL: https://doi.org/10.11114/aef.v7i1.4630
}

\begin{abstract}
The Naturally Optimised Revenue Demand in Communities (NORDIC) model is employed to improve migration. The proposed model produces constructed shadow costs to be inserted into the public budgets to induce economic incentives to improve the integration of immigrants. The resulting shadow cost, and its impact on the PSBR, constitutes a single, key factor that by one digit only expresses how successful the integration is over time. The human tolerance is encapsulated in the launched model through a single factor in the NORDIC model equation that considers the population's general acceptance of immigrants that affects the result. Particularly, the case study shows how refugees should be better integrated into the Swedish society by application of the NORDIC model. The results point at a promising methodology for successfully integrating migrants by using economic instruments. The major conclusion is that the NORDIC model can be used for improving the immigration to a nation. In particular, the suitable level of refugee-reception is possible to determine by employing the NORDIC model in a societal context to improve a nation's GDP and the citizens' welfare. Possible end users are the migration-authorities and politicians that want a comprehensive tool to improve the efficiency of the reception of immigrants and refugees to the current nation. Recommendations for the use of the proposed model are given and further research suggested.
\end{abstract}

Keywords: NORDIC model, economic incentives, integration, refugees, human tolerance

\section{Introduction}

Ever more attention is devoted to the migration issue. The impact of the reception of refugees on the public economy is crucial (Ruist, 2018) making the present work important. This paper is required to alleviate the nations' immigration-burden and make the reception of refugees more cost-effective and human. The objective of this paper is to provide a new and practical method to decide the suitable amounts of migrants and refugees coming to a nation. The humanitarian aspect, as well as the public economy, is considered when designing a decision-support tool intended for authorities, politicians and common citizens that are interested in migration.

The main goal is to facilitate the daily use of the NORDIC model (Stenis, 2019) by migration authorities and immigration managers. The primary hypothesis of this work is that the flow of migrants through nations can be improved in economic and humanitarian terms by applying the NORDIC model. As a secondary hypothesis, the case study suggests how to improve the domestic integration of refugees. The scientific problem and question are if such integration actually can be enhanced by employing economic instruments? Is that approach feasible or not? The research problem concerns accomplishing a change. The choice of method focuses on stakeholders through case studies to increase the knowledge. An analytical approach is used. The research design features a logical approach in a historical context. That design supports the hypotheses because the logics is inherent in the mathematics used for the design of the NORDIC model, backed up by historical data. Thus, quantitative research methodology dominates. The theoretical implication of the study is the achievement of a better scientific background for public decision-making. The provided tool expands the knowledge required to construct ever more subtle theories.

Relevant know-how is hence accumulated here. The practical implications of the present work are the intended improved situation for refugees in particular and opportunities for leaders to logically explain the reasons for taking certain actions, except from emotional causes. The research gap that this study can fill is the need for new economic instruments to manage migration. The study will contribute to improving the economy, which also improves the living conditions for communities receiving immigrants. The claw is the human aspects. 


\section{Review of the Literature}

As regards works by other scholars, for example, Preston (2014) studied the effect of immigration on public finances concerning the sensitivity of the public expenditure to immigration and how it will vary depending upon the composition of public spending and affects the costliness of provision to natives. Ruist (2015) studied the fiscal cost of refugee immigration to Sweden with emphasis on evaluation of the size of the fiscal burden and the net fiscal redistribution to the refugees in Sweden. Åslund et al. (2017) studied the labour market entry of non-labour migrants to Sweden. Bevelander (2011) studied the employment integration of resettled refugees, asylum claimants, and family reunion migrants in Sweden, and Bratsberg et al. (2017) studied the immigrant labour market-integration across admission classes. No similar approaches exist to by just a single key factor, over time, improve the nations' refugee-reception.

\section{Research Methods}

The basis for the work is the existing NORDIC model (Stenis, 2019). The components of the NORDIC model were studied and adapted to particularly migration issues.

\subsection{The Subjects}

The new approach is tested on particularly the refugees to Sweden in a case study with real-world facts and figures. The nation of Sweden was chosen as the object of a case study, because Sweden offers an extensive immigration-tradition that provides a multitude of relevant data.

\subsection{The Procedures Used in the Study}

\subsubsection{Experimental Interventions}

Except from personal computers, no mechanical apparatus was used. This was not required due to the detached approach by the author. Therefore, no direct intervention took place, really.

\subsubsection{Sampling Procedures and Sample Size}

Collection of data from public sources on the Internet was used as the sampling method. The sampling plan was to find as recent and reliable data as possible, featuring a high percentage of the involved, approached objects. No agreements or payments were made to the objects of study. No agreements were made with any institutional review-board due to the author's self-sufficient work. Ethical standards are met because no living individuals or animals were physically involved in the very study. Thus, no safety monitoring procedures were required.

\subsubsection{Measurement Approaches}

The methods used to collect data consisted of questionnaires to certain, scientific colleagues and impersonal observations of relevant study-groups, mainly by using a computer. The reliability of multiple observations was granted by consulting reliable sources on the Internet. Thus, no instruments were used, except from personal computers. The evidence of cultural validity consists of mainly impersonal, socio-economic data being used for the studied entities.

\subsubsection{The Research Design}

An introduction gives the background and explains the reasons for performing the study from a scientific point of view. The general theory for the NORDIC model is outlined, followed by a description of how to use the NORDIC model for migration issues, which is specified in the Analysis that follows. Thereafter, a Case study shows how the NORDIC model in practice can solve the question of how to optimise the number of refugees coming to the nation of Sweden. This exemplification is followed by the concluding sections for Results and discussion, Conclusion, Benefits with the proposed model and, finally, Recommendations to authorities, politicians and others. Public information sources were consulted and personal contacts taken.

\subsection{Theory Foundation}

The NORDIC model gives the constructed shadow cost SC

$$
S C=(X / Y) * Z * W=[(V-C) / Y] * Z * W
$$

where

$\mathrm{SC}$ is the shadow cost to be additionally inserted in the accounts of the organisation; $\mathrm{X}$ is the phenomenon to be optimised $=\mathrm{V}-\mathrm{C} ; \mathrm{V}$ is the value of $\mathrm{X} ; \mathrm{C}$ is the cost of $\mathrm{X} ; \mathrm{Y}$ is the total value of the organisation; $\mathrm{Z}$ is the value of the entities connected to $\mathrm{X} ; \mathrm{W}$ is the weight factor for the general impact of $\mathrm{X}$ on society, during a certain period in a certain, administrative unit. Unit: currency, kilogram, litre or Joule. 
3.4 Application of the NORDIC Model to Migration

$$
\begin{gathered}
\text { SC migration }=[(V-C) / M] * P * L * H \\
0<H<100 \text { per cent of the citizens in favour of free immigration } / 100
\end{gathered}
$$

where

$\mathrm{SC}_{\text {migration }}$ is the shadow cost, here a positive value, for the immigration to a nation, impacting the Gross Domestic Product (GDP); $\mathrm{X}$ is the net worth of the immigration to the nation $=\mathrm{V}-\mathrm{C} ; \mathrm{V}$ is the economic value of the immigration to the nation; $\mathrm{C}$ is the cost for the immigration to the nation; $\mathrm{M}$ is the cost of the migration agency in the nation; $\mathrm{P}$ is the value of the products and services by first generation immigrants to the nation; $\mathrm{L}$ is the life expectancy for immigrants to the nation, compared to natives; $\mathrm{H}$ is the human tolerance, Swedish: medmänsklighet, without unit, it is a decimal value. Period: annually. Unit: US dollars.

Table 1 shows the general principle for the use of the shadow cost SC (Ekonomifakta, 2019).

Table 1. The nation's public budget

\author{
Revenues \\ $\mathrm{SC}_{\text {migration }}$ \\ Expenses \\ Public Sector Borrowing Requirement (PSBR)
}

\title{
3.5 Analysis
}

A decreased Public Sector Borrowing Requirement (PSBR), due to a raised SC migration, points at a more successful integration of immigrants. If the PSBR increases due to a declining $\mathrm{SC}$ migration, this calls for action by the migration-authorities.

\subsection{Manual for Practical Application of the NORDIC Model to Migration}

Follow the following steps when applying the NORDIC model to migration issues.

1. Estimate the value of the parameters by consulting public information sources.

2. Calculate the shadow cost SC.

3. Regularly estimate the parameters.

4. Regularly re-calculate $\mathrm{SC}$ to follow its development over time.

5. Take actions if $\mathrm{SC}$ decreases to improve the integration of immigrants to the nation.

Preferably, several parties are engaged to commonly use the NORDIC model through co-operation between the relevant authorities to improve the integration in the current nations.

\subsection{Case Study: Application of the NORDIC Model to Swedish Refugees}

Numerical estimates are highly uncertain but indicate that the net fiscal transfer to the average refugee, over their entire lifetime in Sweden amounts to, on average, USD7400 (74 000 Swedish Crowns) per year (Ruist, 2018). At the end of 2015, the refugee-population in Sweden amounted to 690000 individuals, or 7.0 per cent of the total Swedish population (Ruist, 2018). In March 2019, the Swedish population amounted to 10255102 persons (Statistics Sweden [SCB], 2019). Thus, the number of Swedish refugees is approximately 720000 persons (7\% * 10255102 persons) corresponding to an annual, Swedish refugee-cost of USD5.3 billion (USD7400 * 720000 persons) = (V - C). In 2018, the total cost for the Swedish Migration Agency was USD2.9 billion (SEK29 480 million) (Swedish Migration Agency, $2019)=$ M. The wage gap between immigrants and natives 1 year after arrival is about 60\% (Anderson \& Huang, 2019). The average monthly salary in Sweden is about USD3000 (kSEK30) (SCB, 2019). Thus, the average monthly salary for immigrants to Sweden 1 year after arrival is about USD1200 (40\% * USD3000 per month). The Swedish taxes on paid wages are 31.42 per cent in total. Thus, the average market value per month for a refugee's to Sweden production is about (USD1200 / $(100-31.42 \%))=$ USD1750 or USD21 000 annually. The value of the products and services by the 720000 Swedish refugees hence is approx. USD15 billion (USD21 000 per year $* 720000$ persons) $=$ P. About half of 
the participants in the Swedish integration commitment lack high school education (Ekonomifakta, 2019). Regarding people with primary school education only, Swedes born abroad have slightly higher life expectancy than those born in Sweden, but about the same life expectancy as regards those with high school and university education (SCB, personal E-mail contact $)$ giving $L=[(($ approx. 105\% $* 0.5)+(100 \% * 0.5)) / 100]=1.03$. In 2016, 1.7/4.0 (43\%) of the Swedes wanted to allow immigration of people with another ethnicity than the original population (European Social Survey [ESS], 2019) $=$ H. An exchange rate of 1 USD $=$ approx. SEK10 (May 2019) is used throughout the present study.

Equation (2) gives:

$$
\text { SC refugees }=(\text { USD5.3 billion }- \text { USD2.9 billion }) * \text { USD } 15 \text { billion } * 1.03 * 0.43=\text { USD } 12 \text { billion }
$$

$\mathrm{SC}_{\text {refuges }}$ is added to the public budget of Sweden. Table 2 shows the general impact of the constructed shadow costs on the public finances of the nation of Sweden, receiving refugees.

A decreased PSBR by USD12 billion causes fewer actions from the immigration authorities to improve the integration of refugees to Sweden. If the next estimation of $\mathrm{SC}_{\text {refugees }}$ shows a higher shadow cost, this points at Sweden has become better on integrating refugees.

Table 2. The public budget of Sweden considering the shadow cost SC of refugees.

$$
\begin{gathered}
\text { Revenues } \\
\mathrm{SC}_{\text {refugees }} \text { (GUSD12) } \\
\underline{\text { Expenses }} \\
\text { PSBR (-GUSD12) }
\end{gathered}
$$

\section{Results and Discussion}

The objective of this paper was to provide a new and practical method to decide the suitable amounts of migrants and refugees coming to a nation. The study of similar literature and the performed case studies show that the objective has been accomplished. The humanitarian aspect, as well as the public economy, was to be considered to provide a decision-support tool for authorities, politicians and common citizens interested in migration. The H-factor in (2) and (3) was successfully employed in the case studies to grant the consideration of the humanitarian aspect in public economy whose officials have been given a comprehensive tool.

The main goal was to facilitate the daily use of the NORDIC model by migration authorities and immigration managers. This goal is met by the successful adaptation of the NORDIC model to migration issues in this paper, shown by the mathematical accuracy of the revised, and easy to use, model. The realism of the case study supports this statement. The primary hypothesis of this work was that the flow of migrants through nations can be improved in economic and humanitarian terms by applying the NORDIC model. This is proven by the mathematical logics and the realism of the case study pointing at the usefulness of the NORDIC model for these purposes. As a secondary hypothesis, the case study could suggest how to improve the domestic integration of refugees. This is true because the case studies produced realistic and reliable results as regards improvement of the situation for particularly refugees in a certain nation. The scientific problem and question to be solved and answered were if such integration actually can be enhanced by employing economic instruments? Was that approach feasible or not? The useful design of the developed equations and the promising possibility to apply the shadow cost-approach to migrants in general, and refugees in particular, tell us that the answer is yes.

The case study exhibits a reasonable shadow cost of USD12 billion. This promising result points at good usefulness in practice for the proposed methodology. Thus, the general objective for the study to provide migration-authorities with a useful tool is fulfilled. The claw of the model is it's considering the human tolerance, which is encapsulated in a new factor, called $\mathrm{H}$.

Particularly, politicians and other concerned parties, are given a practical tool to over time study the development of the integration into society of immigrants and refugees. This improves the economy and the welfare and reduces the human suffering among the many concerned citizens. 
The NORDIC model does not determine in detail which solutions to implement. It provides managers with an overview that presents a general picture of the situation. This is how economic instruments work. The NORDIC model also includes a stepwise, practical manual presented in section 3.6.

The disadvantage with the model is its less good accuracy as regards pinpointing specific sub-groups. Further research can preferably focus on developing algorithms for societal groups.

The analytic treatment of data consisted of the usage of numerical values in the developed expressions. The methods used support their analytic burdens due to the equations mirroring well the reality that is intended to be influenced. Therefore, the methods are robust to violations of the assumptions that underlie them and provide clear insights into the data. Ancillary analyses for statistical error rates are less important to perform in this study because basic and easily available data were used throughout. Interventions or experimental manipulations were not used, as intended. The object groups of interest were approached in an impersonal way and hence not directly affected during the performance of the work. The author was highly detached.

The correctness of the employed mathematics in (2) and (3) grants the reliability of this study. The validity is ensured by the use of commonly known economic theory as basis for the work.

\section{Conclusion}

The NORDIC model can indeed be used for improving the migration to a nation. In particular, the suitable level of the refugee-reception is possible to determine by employing the NORDIC model in a societal context to improve a nation's GDP and all the citizens' welfare.

The work contributes to the literature by providing novel solutions to promote the integration of immigrants and to assist the public managers, to improve their authorities' performance. This improved management situation, mainly in the public sector, is the major value of scientific knowledge added by this novel paper. The findings also impact the private migration-businesses.

The real finding of the present study is that the NORDIC model represents a versatile theory to improve the situation for migrants and refugees in various entities, such as nations. The evidence for this statement consists of the realistic results of the performed case study with real world data. The major novelty of the approach is the innovative usage of shadow costs to create the economic incentives for improvement of the functionality of nations' immigration systems.

The introduction of a single key indicator ( $\left.\mathrm{SC}_{\text {migration }}\right)$ to monitor most aspects of interest for an immigration system is a highlight of this work. The most interesting findings in this study are the method to facilitate the immigration managers' policy decisions, and the positive impact on the humanitarian situation as expressed by the $\mathrm{H}$-factor in (3). That is also the big claw of the work.

\subsection{Benefits}

1. Migration authorities obtain a tool to improve the reception of refugees.

2. The personal suffering is reduced due to immigrants fitting in better in society.

3. The proposed method is based on common economic and mathematic theory.

\subsection{Recommendation}

Apply the NORDIC model to migration issues in general and refugee issues in particular; employ the NORDIC model to determine and optimise suitable, national immigration levels.

\section{References}

Anderson K. H., \& Huang Z. (2019). Can immigrants ever earn as much as native workers? IZA World of Labor 2019, 159(2). https://doi.org/10.15185/izawol.159.v2

Åslund, O., Forslund, A., \& Liljeberg, L. (2017). Labour market entry of non-labour migrants - Swedish evidence, Nordic Economic Policy Review: Working paper 2017, 15, 115-158.

Bevelander, P. (2011). The employment integration of resettled refugees, asylum claimants, and family reunion migrants in Sweden, Refugee Survey Quarterly, 30, 22-43. https://doi.org/10.1093/rsq/hdq041

Bratsberg, B., Raaum, O., \& Røed, K. (2017). Immigrant labor market-integration across admission classes, IZA Discussion Papers, No. 10513, Institute of Labor Economics, [IZA], Bonn.

Ekonomifakta. (2019). Education level - born abroad, Swedish: Utbildningsnivå - utrikes födda, in Swedish. Retrieved from https://www.ekonomifakta.se/Fakta/Arbetsmarknad/Integration/Utbildningsniva/

European Social Survey, [ESS]. (2019). Attitudes to immigration into European countries (2002-2016), Swedish: Attityder till invandring $i$ europeiska länder (2002-2016), in Swedish. Retrieved from 
http://www.delmi.se/migration-i-siffror\#!/attityder-till-invandring-i-europeiska-lander-2002-2012

Preston, I. (2014). The effect of immigration on public finances, Economic Journal, 124, 569-592. https://doi.org/10.1111/ecoj.12180

Ruist, J. (2015). The fiscal cost of refugee immigration: the example of Sweden, Population and Development Review, 41, 567-581. https://doi.org/10.1111/j.1728-4457.2015.00085.x

Ruist, J. (2018). Time for integration - an ESO report on the background of refugees and establishment on the labour market, Swedish: Tid för integration - en ESO-rapport om flyktingars bakgrund och arbetsmarknadsetablering. The Swedish Government Offices, Treasury, Report to the Expert group on studies of public economy 2018:3, in Swedish.

Statistics Sweden, [SCB]. (2019). Preliminary population statistics 2019. Retrieved from https://www.scb.se/en/finding-statistics/statistics-by-subject-area/population/population-composition/population-st atistics/pong/tables-and-graphs/monthly-statistics--the-whole-country/preliminary-population-statistics-2019/

Stenis, J. (2019). An economic instrument to improve communities. Theoretical Economics Letters, 9, 1804-1816. https://doi.org/10.4236/tel.2019.96115

Swedish Migration Agency. (2019). Annual report 2018, Swedish: Årsredovisning 2018, in Swedish. Retrieved from https://www.migrationsverket.se/download/18.748d859516793fb65f91654/1550847536193/Migrationsverket_Års redovisning_2018.pdf

\section{Copyrights}

Copyright for this article is retained by the author, with first publication rights granted to the journal.

This is an open-access article distributed under the terms and conditions of the Creative Commons Attribution license which permits unrestricted use, distribution, and reproduction in any medium, provided the original work is properly cited. 